\title{
多措并举助推水利高质量发展
}

\author{
刘岗 ${ }^{1}$ 刘雨 $^{2}$ \\ 1 延安市南泥湾开发区管理委员会 2 宝塔区水土保持工作队 \\ DOI:10.32629/hwr.v4i8.3285
}

\begin{abstract}
[摘 要] 2020年是我国全面建设小康社会的决胜之年,作为新时代水利人,我们要认真学习贯彻国家领 导人重要讲话精神,要坚持 “节水优先、空间均衡、系统治理、两手发力” 的治水思路,按照 “补短板、 强监管、走前列” 的要求, 全面提升水利治理体系和治理能力现代化。水安全是涉及国家长治久安的大 事, 水利是经济社会可持续发展的基础保障, 高质量发展是提升水安全保障能力的科学途径, 是水利现代 化的根本方法。本文重点探究了推进水利高质量发展的策略。
\end{abstract}

[关键词] 水利; 高质量; 发展

中图分类号：TV213.4 文献标识码：A

\section{1 水利发展的任务}

推进水利高质量发展, 首先需要明 晰水利发展的目的和任务, 针对目的研 究高质量发展的目标, 围绕任务研究高 质量发展的路径。

\section{1水利发展的目的}

水是基础性的自然资源、战略性的 经济资源、环境和生态的基本要素, 有 水之地, 是生命的繁盛之处, 是人类的 宜居之所, 水资源的禀赋条件是国土资 源可利用价值的决定性因素之一。水更 是万物之母、生存之本、文明之道, 人 水关系是人类社会发展的基本问题, 水 安全既涉及饮水保障、粮食供给、防洪 保安等人类生存基本问题, 也涉及经济 发展、环境保护、生态安全等可持续发 展战略问题。

水利作为保障水安全的基本工具, 伴随着农耕文明的兴起而兴起, 伴随着 工业文明的兴盛而兴盛, 并与国家的兴 衰关系密切。水利发展的任务是经济社 会发展所赋予的, 不同的地域条件, 不同 的经济社会发展阶段, 水利发展的任务 和重点不同, 并随着人类对文明认识水 平的提升而跨越发展。但是, 为经济社会 发展提供可靠的水安全保障, 一直是水 利发展的根本目的。

1. 2 水利发展的任务

人类要生存发展, 就要开发利用水
资源以及河湖范围内的水力、水域、砂 土、岸线、航运、生物、景观等各类资 源, 规避洪、潮、涝、旱等各种自然灾害 风险, 为此需要实施水治理, 获得宜居家 园。人类对水系统的干预, 尤其是水资源 及其相关资源的开发利用, 带来人水关 系的变化, 以及与水关联的人与人之间 关系的变化, 如果处理不当, 就会产生人 与水争地、人与人争水争资源等矛盾, 为此需要实施水管理, 实现水事秩序的 和谐与稳定。此外, 水资源作为环境与生 态的基本要素, 具有时空分布不均匀、过 程随机性大、关联因素多等特点, 如果过 度开发与不合理利用, 会造成资源的枯 竭、环境的污染、生态的损害等问题, 为此需要实施水保护, 实现资源的可持 续利用。水治理、水管理、水保护构成 水利工作的基本任务。

\section{2 农业水利工程现状分析}

2.1 相关资金投入的数量较少

从当前的情况来看, 我国的工业与 第三产业的发展速度非常快, 但是与此 同时, 农业的发展却陷入了困境, 速度 日益放缓。对于很多政府部门而言, 主 业并非农业, 由此导致农行水利工程建 设工作被严重阻碍, 一些地方政府部门 缺少一定的热情与积极性, 重视程度严 重不足, 使所投入的资金数量较少。无 论是农民打工获取的经济收入, 还是农
业生产获得的经济收入, 均表现出不断 降低的势态。并且, 由于很多生活与生 产用品的价格日益提高, 造成农业生产 的经济成本随之增长。面对此种情况, 使广大农民从事农业活动的热情严重 降低, 带给农业发展很大的不良影响, 由此形成了投入资金数量不够的现象。 显而易见, 因为资金数量的不足, 造成 了农业水利工程建设工作无法正常开 展, 难以发挥出农业水利建设工程项目 应有的作用和功效。所以, 此项问题是 不容忽视的。

2.2有关农业水利管理部门没有发 挥出自身职能与责任

对于农业水利工程项目的建设而言, 相关水利工程管理部门具有一定的监管 责任。但是从目前有关水利工程管理部 门的职责落实状况来看, 却表现出下述 几个方面的问题: 其一为无法完成对水 利工程项目施工现场实地考察的任务, 由此造成难以深入掌握广大农民的具体 需要、水利工程项目的布设以及实际的 运作状况等, 影响到农业水利工程项目 的正常建设工作; 其二, 无法系统了解到 施工现场的具体状况, 部分水利工程管 理部门只依靠年终总结与季度性报告等 文件资料进行水利工程项目运行情况的 分析与判断, 显然并不准确; 其三, 无法 凸显出战略发展规划的作用。一方面, 
有关战略发展规划的落实与既定的目标 存在着很大的差距; 另一方面, 所获取 的相关数据信息的精准性较低, 形成一 定的偏差, 由此造成所制定的战略决策 脱离了原有的计划轨道, 产生了不良的 影响, 因此, 该项问题的重要性是显而 易见的。

\section{3 水利高质量发展的策略分析}

水利高质量发展, 需要尽快解决水 安全方面存在的突出问题、加快补齐水 安全综合保障能力的短板, 更需要尽快 转变治水理念和治水思路、加快提升水 治理体系和治理能力的现代化水平。

\section{1 更新发展理念}

理念更新是水利高质量发展的关 键。坚持以人为本、共享发展, 着力解决 公众最关心最直接最现实的水安全问题, 保障经济社会可持续发展。坚持生态优 先、绿色发展, 探索人水和谐的空间格 局、产业结构和生产生活方式, 形成科学 合理的水资源开发利用模式。坚持系统 治水、协调发展, 统筹解决洪涝灾害频 发、水资源短缺、水生态损害、水环境 污染等新老水问题, 提高水利综合保障 能力。坚持改革突破、创新发展, 破解约 束水利发展的体制机制性障碍, 推进水 治理体系和治理能力的现代化。

\section{2 加强基础研究}

基础研究是水利高质量发展的前 提。加强水文、水质、生态、工情、灾 情等基本信息的系统监测, 推进河湖健 康评价和水安全能力评价, 健全水资源 公报、水土保持公报、水利发展公报等 制度。建立健全科研院所与水行政主管
部门战略协作机制, 坚持问题导向, 把握 区域特点, 突出基础理论、先进实用技 术、政策法规的研究, 强化实验和试点工 作, 为高质量发展提高科学依据。

3. 3 完善顶层设计

顶层设计是水利高质量发展的指 南。健全水法规体系, 突出水治理措施系 统性、水管理流域整体性、水保护社会 协同性, 完善水利高质量发展政策, 进一 步推进水利体制与机制改革。完善水利 规划体系, 强化水管理、水保护方面的规 划研究, 形成水治理、水管理、水保护和 行业发展的综合体系, 健全规划后评价 与滚动修订机制, 提高规划的前瞻性、综 合性、可操作性, 规范规划符合性审查。 加强水利技术标准、规范、规程的制定 和实施, 突出新问题处置、新技术应用有 关导则制定, 提高水利高质量发展的整 体推进水平。

\section{4 强化创新引领}

改革创新是水利高质量发展的动 力。加强科技创新与应用, 突出节约用 水、水污染防治和河湖生态修复技术的 创新, 加快推进互联网、大数据、人工智 能等高新技术与水利融合力度。加强水 利体制机制改革, 深化河长制湖长制下 水治理、水管理、水保护制度的创新, 突出流域综合管理架构的完善, 形成良 性发展机制。鼓励扶持水利高质量发展 试点, 积累经验, 培育典型, 稳步推广, 引 领发展。

\section{4 结语}

水利是国民经济的基础产业和基础 设施, 具有 “兴利” 和 “除害” 的功能,
水利工程则是水利经济的载体。水利作 为国民经济的基础产业和基础设施, 其 对于国民经济的发展显然也具有一定的 拉动作用。水利是国民经济和社会发展 的基础和命脉, 保障水利建设有稳定的 投资来源, 是经济稳定、持续、健康发展 的需要。水利作为国民经济的基础和基 础产业, 必须保持与经济和社会的协调 发展, 必须满足不同时期经济社会发展 对水利的要求, 因此研究如何推进水利 高质量发展具有重大的意义。

\section{[参考文献]}

[1]杨晓茹.水利发展规划的未来趋势 分析[J].水利规划与设计,2017(11):15-20.

[2]马林云.补短板强监管走前列推 进浙江水利高质量发展 [J]. 中国水 利,2019(24):73.

[3]陈杰.全面推动江苏水利高质量 发展 [J].江苏水利,2019(04):1-4.

[4]杜威漩.农田水利设施供给质量缺 憾及其改善[J].中州学刊,2020(02):26-32.

[5]王博,万晶晶, 朱玉春.制度能力 对农户合作供给农田灌溉系统的影响分 析——基于黄河灌溉区6省份的调查数 据[J].农业技术经济,2020(02):32-44.

[6]区小兰.村庄公共品供给中“政 府失灵”的成因及其路径重构一一基于 公共选择理论视角 [J]. 当代农村财 经,2019(04):24-29.

[7]刘辉,张慧玲.小型农田水利治理 主体行为的博弯分析——基于丘陵山区 三家馆乡、溪口镇的调查 [J]. 农村经 济,2018(10):111-115. 